\title{
Constructing Identities: Amos Tutuola and the Ibadan Literary Elite in the wake of Nigerian Independence
}

\author{
Mackenzie Finley \\ Department of History \\ University of Texas at Austin \\ mackenziejfinley@gmail.com
}

\begin{abstract}
With Nigerian novelist Amos Tutuola as primary subject, this paper attempts to understand the construction of sociocultural identities in Nigeria in the wake of independence. Despite the international success of his literary publications, Tutuola was denied access to the most intimate discourses on the development of African literature by his Nigerian elite contemporaries, who emerged from University College, Ibadan, in the 1950s and early 1960s. Having completed only a few years of colonial schooling, Tutuola was differentiated from his elite literary contemporaries in terms of education. Yet if education represented a rather concrete, institutionalized divide between the elite and the everyday Nigerian, this paper will suggest that the resulting epistemological difference served as a more fluid, ideological divide. Both Western epistemology, rooted in Western academic spaces, and African epistemology, preserved from African traditions like proverbs and storytelling, informed the elite and Tutuola's worldviews. The varying degrees to which one epistemology was privileged over the other reinforced the boundary between $\mathrm{Tu}$ tuola and the elite. Furthermore, educational experiences and sociocultural identities informed the ways in which independent Nigeria was envisioned by both Tutuola and the elite writers. While the elites' discourse on independence reflected their proximity to Nigeria's political elite, Tutuola positioned himself as a distinctly Yoruba writer in the new Nigeria. He envisioned a state in which traditional knowledge remained central to the African identity. Ultimately, his life and work attest to the endurance of indigenous epistemology through years of European colonialism and into independence.
\end{abstract}


During a lecture series at the University of Palermo, Italy, Nigerian novelist Amos Tutuola presented himself, his work, and his Yoruba heritage to an audience of Italian students and professors of English and Anglophone literatures. During his first lecture, the Yoruba elder asked his audience, "Why are we people afraid to go to the burial ground at night?" An audience member ventured a guess: "Perhaps we are afraid to know what we cannot know." Tutuola replied, "But, you remember, we Africans believe that death is not the end of life. We know that when one dies, that is not the end of his life [...] So why are all people afraid to go to the burial ground at night? They're afraid to meet the ghosts from the dead" (emphasis in original). ${ }^{1}$

Amos Tutuola (1920-1997) was recognized globally for his perpetuation of Yoruba folklore tradition via novels and short stories written in unconventional English. His works, especially The Palm-Wine Drinkard (1952) and My Life in the Bush of Ghosts (1954), were translated into numerous European languages, including Italian. Given the chance to speak directly with an Italian audience at Palermo, Tutuola elaborated on the elements of Yoruba culture that saturated his fiction. His lectures reflected the same sense of purpose that drove his writing. Tutuola explained, "As much as I could [in my novels], I tried my best to bring out for the people to see the secrets of my tribe-I mean, the Yoruba people - and of Nigerian people, and African people as a whole. I'm trying my best to bring out our traditional things for the people to know a little about us, about our beliefs, our character, and so on."2 Tutuola's didactics during the lecture at Palermo reflect his distinct intellectual and cultural commitment to a Yoruba cosmology, one that was not so much learned in his short years of schooling in the colonial education system as it was absorbed from his life of engagement with Yoruba oral tradition.

With Tutuola as primary subject, this paper attempts to understand the construction of sociocultural identities in Nigeria in the wake of independence. The educated elite writers, such as Wole Soyinka and Chinua Achebe, who emerged from University College, Ibadan, during the same time period, will serve as a point of comparison. On October 1, 1960, when Nigeria gained independence from Britain, Tutuola occupied an unusual place relative to the university-educated elite, the semi-literate "average man," the international

1 Alassandra di Maio, Tutuola at the University: The Italian Voice of a Yoruba Ancestor, with an Interview with the Author and an Afterword by Claudio Gorlier (Rome: Bulzoni, 2000), 38. The lecture's transcriber utilized graphic devices (italicized and bolded words, brackets denoting pauses and movements) to preserve the dynamic oral experience of the lecture. However, so that the dialogue reads more easily in the context of this paper, I have removed the graphic devices but maintained what the transcriber presented as Tutuola's emphasized words, simply italicizing what was originally in bold.

2 Di Maio, Tutuola at the University, 148. 
stage of literary criticism, and the emerging field of African literature. This position helped shape his sense of identity. Despite the success of his literary publications, Tutuola was not allowed to participate in the most intimate discourses on the development of African literature by his elite contemporaries. In addition to his lack of access to higher education, Tutuola was differentiated from his elite literary contemporaries on epistemological grounds. If education represented a rather concrete, institutionalized divide between the elite and the everyday Nigerian, an epistemological difference served as a more fluid, ideological divide. Both Western epistemology, rooted in Western academic spaces, and African epistemology, preserved from African traditions like proverbs and storytelling, informed the elite and Tutuola's worldviews. The varying degrees to which one epistemology was privileged over the other reinforced the boundary between the elite and Tutuola.

This paper draws largely on correspondence, conference reports, and the personal papers of Tutuola and his elite contemporaries housed at the Harry Ransom Center at the University of Texas at Austin, as well as on interviews transcribed by the Transcription Centre in London, the periodical Africa Report (1960-1970), and Robert M. Wren and Claudio Gorlier, concentrating on primary sources produced during the years immediately prior to and shortly after Nigerian independence in 1960. Tutuola's ideas generally did not fit into the sociocultural objectives of his elite counterparts. Though they would come in contact with one another via the world of English-language literature, Tutuola usually remained absent from or relegated to the margins of elite discussions on African creative writing. Accordingly, the historical record has less to say about his intellectual ruminations than about those of his elite contemporaries. Nonetheless, his hand-written drafts, interviews, and correspondences with European agents offer a glimpse at the epistemology and sense of identity of an "average" Nigerian in the aftermath of colonialism and independence.

\section{Constructing identities}

Within the context of decolonization and early independence, Tutuola negotiated his identity and position as a Yoruba novelist in the new Nigeria. The first internationally-recognized English-language author from Nigeria, he also represented the "average man" with limited colonial-style education, basic literacy, a menial job in the government sector, and an attachment to his ancestral village and traditions. When asked about himself, Tutuola would often include information similar to that found in a correspondence with one Michele Dussutour-Hammer (1973): 
I am the native of Abeokuta, one of the biggest town [sic] in the Western State [. . . I am a Yoruba man once Abeokuta is a Yoruba town. But now I live together with my family in Ibadan and I work in the Nigerian Broadcasting Corporation, as a storekeeper. I write at my leisure hours. Each of my books had been written out Yoruba folk-lores, tales, etc. ${ }^{3}$

Tutuola consistently identified himself as a "Yoruba man," a Yoruba writer, a businessman, a husband, and a father. He also grew up in a Christian household and was baptized in $1975 .{ }^{4}$ For the purposes of this paper, however, Tutuola's conception of himself as a Yoruba man and Yoruba writer will be privileged.

As a writer, Tutuola can be positioned alongside his elite literary contemporaries, whose novels and short stories also reached a wide, international audience. The question arises: if both sets of writers achieved national and international literary success, then what distinguished Tutuola from the elite writers to the extent that he remained at the fringes of their discourse on African literature? This paper suggests that the constructed distinction between Tutuola and his elite contemporaries arose from differences in access to education and was reinforced by differences in epistemology. Differences in epistemology ultimately led to differences in the articulated visions for the new Nigeria, which added to the rift between the two groups. Because of his limited education, Tutuola's sense of identity helps us to uncover the ideas and experiences of the "average," semi-literate Nigerian in the immediate aftermath of October 1, 1960. Yet because of his literary success, Tutuola is uniquely positioned to simultaneously blur and define the cleavage between elite and average.

Aside from his novels and short stories, much of what has been preserved of Tutuola's sense of identity exists in the form of recorded interviews with his elite counterparts. Thus, the ways in which Tutuola understood himself were often articulated within the framework of African literary development and progress on both local and global stages. In interviews, especially during his early career, Tutuola limited his commentary to those ideas specifically prompted by the interviewers' questions. For instance, when Nkosi asked Tutuola if he liked "supernatural stories," Tutuola responded without elaboration, "Ah! Well, well, well, of course." Tutuola did not seem compelled to

3 Tutuola, letter to Madame Michele Dussutour-Hammer, September 1, 1973, Box 6, Folder 3, Amos Tutuola Collection, The Harry Ransom Center, University of Texas (hereafter cited as ATC-HRC).

4 Baptism card, July 20, 1975, Box 10, Folder 9 (ATC-HRC).

5 Tutuola, quoted in "Amos Tutuola, Nigeria, August 1962. Interviewed by Lewis Nkosi, South Africa," August 1962, http://www.crl.edu/ (hereafter CRL). 
articulate why he liked such stories. In the same interview, Nkosi asked Tutuola a question that had been directed regularly toward his fellow writers in the early 1960s: "[W] hat made you write?" Tutuola explained, "Well, of course, when I was in the school I always telled school children folklores and from that, having left school, I got the idea to write my own books."

Tutuola's identity was further articulated through his correspondence with foreign literary critics, academics, and publishers. In a letter to Mr. and Mrs. Donald Allen of Grove Press (1953), Tutuola wrote of himself: "I have much aptitude for writing stories and I hope to prove my talent to you in due course."7 Tutuola also received feedback from correspondents, which undoubtedly helped shape his sense of self. Early in Tutuola's career, a European professor at Ibadan, Eric Larrabee, wrote a letter to Tutuola in which he expressed: "Unfortunately he [an unnamed acquaintance of Larrabee] had the idea that 'I discovered you' [. . .] Of course, you discovered yourself." ${ }^{8}$ Correspondence with foreign personalities situated Tutuola in a global context. In a letter from one Klaus-Otto Rond from West Germany (1969), Tutuola was identified as one of the "prominent personalities of our age." In a note from Claude S. Phillips, Jr., Director of the Institute of Regional Studies at Western Michigan University, Tutuola was asked permission for his writing to be included in a new course, titled, "Introduction to the Non-Western World" (emphasis added). ${ }^{10}$

Tutuola's elite contemporaries also commented on his identity and position in the developing sphere of African English-language literature. Tutuola was painted as man who either spearheaded, existed on the periphery of, or reflected badly on Nigerian literary development. Black Orpheus, which was co-edited by Ulli Beier, Wole Soyinka, and Ezekiel Mphahlele, published a review of Tutuola written by Gerald Moore, calling Tutuola a "Nigerian Visionary," though the review ultimately suggested that "Tutuola's value to the rising generation of young African writers is probably that of an example rather than of a model." 11 At the Mbari writers' conference held at Makerere College, Uganda (1962), Tutuola became a topic of brief discussion. Mphahlele reported, "At one stage it was suggested that Amos Tutuola would never have

\footnotetext{
6 Ibid.

7 Tutuola, letter to Mr. and Mrs. Donald Allen, March 24, 1953, Box 6, Folder 1 (ATC-HRC).

8 Eric Larrabee, letter to Tutuola, December 23, 1953, Box 6, Folder 1 (ATC-HRC).

9 Klaus-Otto Rond, letter to Tutuola, September 12, 1969, Box 6, Folder 2 (ATC-HRC).

10 Claude S. Phillips, Jr., letter to Tutuola, January 27, 1961, Box 6, Folder 2 (ATC-HRC).

11 Gerald Moore, “Amos Tutuola: A Nigerian Visionary," Black Orpheus 1 (Sept. 1957): 27-35; reprinted in Lindfors, Critical Perspectives on Amos Tutuola, 57.
} 
been published if the rejection or acceptance of his manuscripts depended on the views of an African reader. Although Palm Wine Drunkard [sic] was considered interesting, it was felt that the rest of Tutuola was repetitive." ${ }^{12}$ In a letter to West Africa (1954), I. Adeagbo Akinjogbin wrote, "From the 'portrait' it is clear that the author [Tutuola] is not an academic man and therefore I submit that it is not a high literary standard that has attracted so many European and American readers." ${ }^{33}$

A comparison with Tutuola's elite contemporaries helps to locate the impulses behind such commentary, as well as the ideologies underlying the constructed barrier between Tutuola and the educated elite. The Nigerian literary elite-Christopher Okigbo, Chinua Achebe, Wole Soyinka, J. P. Clark, and others hailing from University College, Ibadan (UCI) - negotiated their identities in exclusive academic spaces. Spaces like the Mbari Writers' and Artists' Club of Ibadan, Nigeria, and Black Orpheus, a literary journal, gave rise to existential questions: "How important is the African novel? [. . .] How does an African writer face up to the problem of translating into a foreign language thoughts and feelings that ordinarily operate in his mother tongue? [. . .] Does the fact that an African writer has to be published overseas not demand from him a false tone?"14 The questions themselves and the responses they generated demonstrated the struggle among the Ibadan writers to formulate an understanding of "Africanness" in relation to their creative work and their elite position within the newly independent Nigerian context.

The boundaries of the university space provided a material separation between Tutuola and the elite. As students, the elite writers viewed themselves as being a part of the intellectual heart of Nigeria. The university's setting at Ibadan was significant. In 1962 South African novelist Lewis Nkosi describes Ibadan as "truly an African city with no counterpart anywhere in Europe [. . .] the very spirit which motivates city life is uniquely African"15 From within the Ibadan setting, the literary elite negotiated definitions of "African nation" and "African culture." Novelist Vincent Chukwuemeka Ike recalls: "We had a Society for the Study and Promotion of African Culture. The phrase 'African bias' was a strong phrase then. We were emerging as a young nation; we

12 Ezekiel Mphahlele, copy of a report on the writers' conference held at Makerere College, Kampala, Uganda, June 8-17, originally published in Africa Report, July 1962; Box 1, Folder 3, Transcription Centre Papers (HRC).

13 I. Adeagbo Akinjogbin, in West Africa, June 5, 1954; reprinted in Lindfors, Critical Perspectives on Amos Tutuola, 41. "Portrait" refers not to a photograph but to a short biography of Tutuola printed in the journal.

14 Ezekiel Mphahlele, “The Makerere Writers' Conference,” Africa Report, 7, no. 7 (Jul 1, 1962), 7.

15 Lewis Nkosi, “African Literature, Part II: English-Speaking West Africa," Africa Report (Dec 1, 1962), 15. 
ought to demonstrate Africanness. We were trying to project our personality [...] You have to assert your identity."16

In addition to setting themselves apart locally, the elite sought to establish themselves as distinctly African writers globally. The ways in which the elite distinguished themselves as "Africans" from the rest of the world becomes apparent in their discourse on Pan-Africanism. When comparing "African" literature with the literature produced by black Americans, for instance, elite writers often distinguished between a culture that was lived and one that was meant to be retrieved from an imagined past and retained. Okigbo, one of the most outspoken of the Ibadan literary elite against the concept of Pan-Africanism at the time, was not convinced that there was an identifiable link between Africans and black Americans aside from skin color. In an interview with Dennis Deurden (1963), Okigbo suggested, "[T]here might not in fact be any cultural meeting points between the various black peoples of the world [...] I have seen so far no affinity between African literature and negro American literature." ${ }^{17}$ Similarly, in an interview with his Jamaican contemporary Andrew Salkey (1964), J. P. Clark articulated the importance of lived experience in shaping both literature and identity. Referring to his dual experience at University College, Ibadan, and in his home village during the holidays (where "things are pretty much intact [. . . ] as they have always been"), Clark distinguishes between the continental African's and the black West Indian's cultural and epistemological experience: "I suppose this double stream is what you haven't got in the West Indies [. . .] All you really have is the English stream." 18

\section{Education and Epistemology}

The elites' discourse on Pan-Africanism introduces two significant points of discussion related to education and the development of identities in mid-twentieth-century Nigeria. First, when studying the divide between elite and average in terms of education, various forms of education, including lived experiences, should be considered. Just as lived experiences set the elite apart from writers in the African diaspora, they also contributed to the cleavage between the elite and Tutuola. Secondly, the confluence of African and Western epistemologies in colonized African spaces created a syncretic intellectual culture with which Tutuola and the elite engaged. The particular spaces in which the epistemologies were negotiated impacted the degree to which one form of

16 Vincent Chukwuemeka Ike, interview by Wren, Those Magical Years, 72.

17 Okigbo, quoted in "Christopher Okigbo, Nigeria, August 1963. Interviewed by Dennis Duerden, United Kingdom” (CRL).

18 Clark, quoted in "John Pepper Clark, Nigeria, January 1964. Interviewed by Andrew Salkey, Trinidad,” (CRL). 
knowledge was privileged over the other. Because of his limited time spent in the colonial education system, Tutuola adopted less of the new and retained more of the old. Meanwhile, the academic spaces of the elite produced new language with which to understand themselves, their work, and their position in the new Nigeria. This section will elaborate on the educational experiences of Tutuola compared to the elite and seek to understand the resulting epistemological divide between elite and average.

Tutuola's view of himself and his position in society were informed by the multifarious forms of education he received. On the one hand, Tutuola spent relatively little time in the colonial education system. While in the classroom, however, he encountered Nigerian folklore. For instance, in a letter to Bernth Lindfors (1968), Tutuola informed Lindfors that he had read Chief Fagunwa's first novel, Ogboju-Ode Ninu Igbo Irunmale, while in school. ${ }^{19}$ Tutuola's daily life must have been saturated with Yoruba oral tradition. In fact, Tutuola explained in an interview with Nkosi (1964), "[F]rom the beginning I always liked to listen to the old people in my village when they were telling short stories in the night." ${ }^{20}$ Yet its presence in the colonial schoolhouse and in printed literature undoubtedly reinforced its cultural and epistemological validity, at least at an unconscious level. Later in his life, Tutuola endeavored to enhance his education through additional reading. He received books, including Carson McCullers' The Heart Is a Lonely Hunter, William Faulkner's The Old Man, and a pocket thesaurus, from foreign publishers and critics with whom he was in contact. ${ }^{21}$

Tutuola actively sought career-related education, both for business and for writing. While employed at the Nigerian Broadcasting Company, for instance, he completed a course on "Management of Stores and Stock Control," in which he learned (among other practical lessons) that "climate and geopolitical conditions may affect production transportation." 22 He was also reported to have enrolled in evening classes prior to Nigerian independence in order to "improve' himself, so that he may develop into what he describes as a 'real writer.'" 23 In some of his earliest correspondence with European publishers, Tutuola articulated his desire for education. In a letter to Faber and Faber

19 Letter to Bernth Lindfors from Tutuola, May 16, 1968, Box 6, Folder 2 (ATC-HRC).

20 Tutuola, quoted in "Conversation with Amos Tutuola," Africa Report 9, no. 7 (July 1, 1964): 11 .

21 Donald Allen, letter to Tutuola, April 3, 1953, Box 6, Folder 1 (ATC-HRC); Tutuola, letter to Donald Allen, March 24, 1953, Box 6, Folder 1 (ATC-HRC).

22 "Management of Stores and Stock Control" course handbook, 1967, Box 10, Folder 8 (ATC-HRC).

23 "Portrait: A Life in the Bush of Ghosts,", West Africa (May 1, 1954), in Critical Perspectives on Amos Tutuola, ed. Bernth Lindfors (Washington, D.C.: Three Continents Press, 1975), 35-38. 
on March 21, 1952, Tutuola requested financial assistance to further his education "in a Private Institution overseas," in order to "lay hand on any avenue which may open its way to making me a better man in life." ${ }^{24}$

Tutuola received both invited and uninvited educative feedback via correspondence with foreign publishers and critics. ${ }^{25}$ In a letter (unsigned) from Grove Press (1953), Tutuola was acquainted with a style of criticism akin to that which he may have received had he spent more time in elite academic spaces:

Sometimes I think that the endings of your stories are rather weak. They might be more definite. We should know that the story is finished. The story should have a beginning, middle, and end. Also they (your stories) are sometimes too complicated. You start one story and then bring in another story, and the reader gets confused about what happened to the first story. Other than that they are very good. Your language is wonderful. ${ }^{26}$

In a letter from a Dutch critic, Tutuola encountered Western conflicts of religious opinion in a review of his work: "The only thing I regret [about Ajaiyi and His Inherited Poverty (1967)] is the beginning [. . . and the end about Christianity being the only religion with the only God and the building of the churches. This will be cheered by the conservative Europeans." ${ }^{27}$

Outside of the formal workplace and apart from his endeavors in the world of literature, Tutuola engaged with the epistemology of Yoruba proverbs and folktales. Nigerian literary scholar Emmanuel Obiechina explains the didactic intentions of proverbs in Yoruba society: "Proverbs are the kernels that contain the wisdom of a people. They are usually philosophical or moral expositions reduced to a few words, and form a mnemonic device in societies in which everything worth knowing and relevant to day-to-day life of the people has to be committed to memory." ${ }^{28}$ In a 1962 interview, Nkosi and Tutuola discussed the inspiration behind Tutuola's writing. Nkosi inquired of

24 Tutuola, letter to Faber and Faber, March 21, 1952, Box 7, Folder 2 (ATC-HRC).

25 We learn through a letter from Donald Allen at Grove Press that Tutuola at least once invited feedback. In a letter dated May 13, 1953, Allen wrote, "You ask me to tell you what we think of the short stories-I feel that your writing in THE PALM-WINE DRINKARD is somewhat more interesting to American readers. They like, as do we, particularly what we call fantasy ..." Box 6, Folder 1 (ATC-HRC).

26 Unsigned letter to Tutuola, June 13, 1953, Box 6, Folder 1 (ATC-HRC).

27 Letter to Tutuola (sender address includes "Holland"), November 26, 1967, Box 6, Folder 2 (ATC-HRC).

28 Emmanuel Obiechina, "Amos Tutuola and the Oral Tradition," in Language and Theme: Essays on African Literature (Washington, D.C.: Howard University Press, 1990), $22-23$. 
the content of Tutuola's work: "[A]re they the stories that have been told to you by the old people, or are they the stories you invent yourself?" Tutuola responded, "No, they are the stories we are told by the old people" (emphasis added)..$^{29}$ Tutuola's education within the framework of Yoruba storytelling had taught him that he was part of a collective who exchanged folktales and proverbs as part of everyday life.

Meanwhile, the colonial university, the academic journals, publishing houses, and the conference spaces in which the elite negotiated their identity were in many ways anchored in Western Europe. In an interview with Wren (1983), Ben Obumselu recalls his experience at University College, Ibadan: "[Eric Robinson] was my first English teacher, and he made me see the world in an entirely different way [...] I saw him as a person dedicated to knowledge and to nothing else."30 Obumselu's statement conveys the sense that "knowledge" came from the ivory tower, rather than from indigenous oral tradition. Among the literary elite, questions of identity were often reframed in academic literary terms. Conceptions of African identity were informed by investigations into the nature and definition of African literature. "What is African literature?" often led to "What is African?", when the question was raised at academic conferences like the Mbari writers' and artists' club in 1962. Summarizing the collective agenda of African elite writers, the narrator of an "Africa Abroad" radio segment described the literati as "ferociously literate young men, burning with a desire to articulate some of the fundamental concepts underlying the structures of African societies, the principles upon which the art and literature of Africa are founded." 31

The Nigerian literary elite also raised and confronted questions of identity in foreign education spaces. Travel opportunities, available only to those who could afford to go, sent the African literati to Europe and the United States, and across Africa more broadly, thus elaborating their self-consciousness. Soyinka, for example, supplemented his time at Ibadan by earning a degree from Leeds University and participating with the Royal Court Theatre in London before returning to Nigeria in 1960. While at Leeds, Soyinka undoubtedly encountered moments of positive reception. However, it was the aversion of a female peer that warranted inclusion in a letter to his friends at Ibadan. Obumselu recalled the letter two decades later during an interview with Robert M. Wren:

29 "Amos Tutuola, Nigeria, August 1962. Interviewed by Lewis Nkosi, South Africa," August 1962 (CRL).

30 Ben Obumselu, interview by Wren, Those Magical Years, 91.

31 Narrator quoted in "African writers: Ali Mazrui, Nov 1962, 'The Mind of Africa' by W. Abraham," Africa Abroad 15 (November 15, 1962) (CRL). 
[The letter] was about how he went to a dance and he found a girl staring at him all the time. He was mulling over in his mind how he'd made this conquest and how he was going to play his cards so that he would not miss. So in the end he went up and spoke to the girl. And the girl says, she must have said, "I wasn't looking at you; I was looking at your nose. I've never seen any nose so big and hideous." ${ }^{2}$

Long stays abroad altered not only self-awareness but perceptions of African literature, as well. South African writer Lewis Nkosi articulated the changes in perspective brought about by extended stays abroad: "[Living in Europe] forces one to acquire some perspective on Africa's achievements [. . .] The claims which often seem credible enough when heard in Cotonou or at the Mbari Club in Ibadan can strike one as vastly comic when re-read in the intensely competitive atmosphere of Charing Cross Road in London or St.Germain-des-Prés in Paris."33

Though Tutuola and his elite contemporaries did not share the same educational experiences, they both lived at the intersection of African and Western knowledge. In Tutuola's case, this confluence of epistemology manifested itself most obviously in his writing. His work was steeped in Yoruba oral tradition, yet he produced his stories in book form written in the English language. In 1963, Soyinka sought to articulate Tutuola's syncretic epistemology. He explained, "The deistic approach of the Yoruba is to absorb every new experience, departmentalize it and carry on with life." 34 Accordingly, Soyinka described, "This book [The Palm-Wine Drinkard], apart from the work of D. O. Fagunwa who writes in Yoruba, is the earliest instance of the new Nigerian writer gathering multifarious experiences under, if you like, the two cultures and exploiting them in one extravagant, confident whole." ${ }^{35}$ He interrogated Tutuola's writing in this way: "[H]as Tutuola's inspiration in this instance come from folklore? It is likely. Or else from the Sunday Sermon? Death or the Devil winds up the road behind the sinner and he cannot turn back." 36

Not every elite writer acknowledged what Soyinka called the "imaginative duality" of Tutuola's work. To some, Tutuola personified a distinctly Yoruba worldview. Irele has suggested that Tutuola so interiorized elements of Yoruba storytelling as to relive them in his individual consciousness as he organized

32 Ben Obumselu, interview by Wren, Those Magical Years, 94-95.

33 Lewis Nkosi, "Where Does African Literature Go from Here?" Africa Report 11, no. 9 (Dec 1, 1966): 7.

34 Wole Soyinka, "From a Common Backcloth: A Reassessment of the African Literary Image," The American Scholar 32, no. 3 (Summer 1963): 390.

35 Ibid.

36 Ibid., 391. 
them on paper. ${ }^{37}$ Nkosi wrote, "The vitality afforded West African writing by a conscious borrowing from fables, traditional myths, and folklore, is perhaps nowhere better illustrated than in stories by Amos Tutuola, the only Nigerian writer who can be described as a traditional storyteller upon whom European influences are minimal, if not entirely absent." ${ }^{38}$ Meanwhile, as Tutuola repeatedly expressed in interviews, two of his primary intentions in writing were to preserve Yoruba storytelling among a local audience and to introduce Yoruba people to a global audience. Whether Tutuola was a purely Yoruba man as Nkosi suggested or a product of intersecting influences, the degree to which Tutuola retained indigenous epistemology differentiated him from the elite.

The elite also developed a syncretic body of knowledge, which was framed by the language of Western academia. From Tutuola's perspective, the elite all but shed their indigenous knowledges. During the lecture at Palermo, Tutuola explained:

But juju is not so popular these days anymore. For example, well educated young people like you-who go to the university, obtain your degree, and face your learning first, and then your profession-you will not be interested in these things. You have no time for them. Yet, where we can get these things in Nigeria these days is from illiterate people-in other words those who are not educated. ${ }^{39}$

For all their absorption of European epistemology, however, the elite never departed entirely from what Achebe described as the old ways of life. In an interview with Nkosi (1964), Achebe asserted: "I regard myself as very much an African writer. I think I'm basically an ancestor worshipper, if you like. ${ }^{\prime 40} \mathrm{Il}-$ lustrating the tension between Western and indigenous epistemologies, Christopher Okigbo explained in an interview with Robert Segumaga (1965): "I think that it is a lot of nonsense talk, all this we hear nowadays of men of two worlds. I belong integrally to my own society just as I believe I belong also integrally to some other societies other than my own. The truth, of course, is that the modern African is no longer product of an entirely indigenous culture." 11

37 Irele, "Tradition and the Yoruba Writer: D. O. Fagunwa, Amos Tutuola, and Wole Soyinka," Odu 11 (Jan. 1975): 87.

38 Nkosi, "African Literature, Part II," 15.

39 Tutuola, quoted in di Maio, Tutuola at the University, 55.

40 Achebe, "Conversation with Chinua Achebe," 20.

41 Okigbo, quoted in "Christopher Okigbo, Nigeria, July 1965. Interviewed by Robert Serumaga, Uganda” (CRL). 
Tutuola and the elite did not merely recognize their differences in epistemology, but they also distinguished themselves from one another along epistemological lines. Thus the cleavage between elite and average widened, especially as elite education became the new standard and Tutuola felt the limitations of his truncated classroom experience. In a report titled "A Brief Explanation of My Journey to America and London," which Tutuola wrote in 1983 following his visits abroad, the Yoruba writer lamented: "[M]ost of our well educated men, especially young men and women hide in them the truth of our customs, etc. They know that all are true but being they are ashamed of them or to disclose them to other people that they are true, they simply call them 'superstitions." ${ }^{42}$ Again, in his lecture series at Palermo, Tutuola distinguished between himself and his elite counterparts by referring to the epistemological effects of Westernized education: "I don't know whether those people who were well educated were ashamed of their own heritage. I wonder why they did not want to write anything concerning their tradition." 43

The elite likewise set themselves apart. In the early years of independence, some of the literary elite began to defend the value of Tutuola's writing for its uniquely African qualities. Yet, as a whole they continued to point out the insufficiency of his education in relation to their own. In a radio segment about Tutuola (1967), narrator Alex La Guma summarized the views of many educated elite:

To many educated West Africans and potential writers it came as a surprise, even a shock that the first West African novel to be published in English and to make an impact on the European scene should be The Palm Wine Drinkard. For the writer of this landmark in Nigerian literature was a man who had had a minimum of formal education [. . .] Indeed, Tutuola's books are clearly those of a man never trained with models of English style, and many who recognised his ability still felt that his work would never amount to much until he had been better educated in the art of writing. ${ }^{44}$

Similarly, five years earlier Nkosi had reported that the "younger West African writers remain skeptical of Mr. Tutuola's talents [...] [T] hey suspect that his lack of inhibitions in the use of language is largely attributable to an

42 Tutuola, “A Brief Explanation of My Journey to America and London (1983)," Box 1, Folder 2 (ATC-HRC).

43 Tutuola, quoted in di Maio, Tutuola at the University, 53.

44 "African writers: Alex La Guma on Amos Tutuola, Jan 1967" (CRL). 
inadequate education." ${ }^{\text {45 }}$ Clearly a new kind of knowledge and accompanying skill set had usurped the position of older knowledges among the elite.

Despite their different educations, Tutuola and the elite shared the idea that the term "education" meant classroom learning in a Western sense. For the elite, the idea was accompanied by assumptions of the objectivity of Western scientific knowledge. The influence of such epistemology can be found in the articulated dichotomy between that which is "academic" and that which is "sensitive" or "full of feeling." In an interview with Dennis Deurden (1963), Christopher Okigbo offers a critique of his contemporary poet, Michael Echeruo: "I found Michael Echeruo's poetry a bit academic. I didn't find sufficient feeling in it" (emphasis added). ${ }^{46}$ Meanwhile, regardless of the pedagogical intentions of Yoruba oral tradition, Tutuola also conceived of education in terms of Westernized academic spaces. He generally employed the term only when referring to academic learning. In a letter to one Mrs. Harding, dated December 22, 1954, Tutuola wrote: "Having failed to help myself to further my education then I came back to Lagos in 1939 [. . .] I started to learn the black's work" (emphasis added). ${ }^{47}$

In tension, therefore, were Tutuola's deep commitment to Yoruba epistemology and his efforts to gain access to a distinctly Western form of education. Was he impacted by the elite idea of education, which was often manifested in condescending reviews of Tutuola's work? On at least one occasion Tutuola is recorded to have read a condescending review of his work. In his report, "A Brief Explanation," Tutuola wrote: "One man called BABALOLA JOHNSON, read the book [The Palm-Wine Drinkard]. Immediately, he wrote a letter to protest to my publishers blamed them that they should have not published my story [. . . since the writer wrote the story in bad English. ${ }^{\prime \prime 8}$ On the other hand, could the significance of the classroom have been reinforced by his own social immobility? Upon requesting a promotion at the Nigerian Broadcasting Corporation where he worked in 1958, for example, Tutuola received this reply from the Director of Programmes: "It was a great pleasure and privilege for me to meet you the other day. As you know, I have long been an admirer of your work"; and yet, "The question of whether any promotion can be found for you within the service is a more complicated one,

45 Nkosi, "African Literature: Part II, English-Speaking West Africa," Africa Review 7, no. 11 (December 1, 1962): 15.

46 Christopher Okigbo, quoted in "Christopher Okigbo, Nigeria, August 1963. Interviewed by Dennis Duerden, United Kingdom” (CRL).

47 Tutuola, letter to Mrs. Harding, December 22, 1954, Box 6, Folder 1 (ATC-HRC).

48 Tutuola, "A Brief Explanation." 
since, as you very frankly said, your educational qualifications were not such as to fit you for rapid advancement." ${ }^{\prime 9}$

Tutuola's social immobility also took the form of geographic immobility. Unlike many of the elite, Tutuola was not afforded the opportunity to travel abroad early in his career. This limitation was a catch-22; it was at once a consequence of limited finances and colonial education and a condition that prevented access to additional education and opportunity in a global context. Thus Tutuola's lack of travel reinforced the division between elite and average. Nevertheless, Tutuola desired geographic mobility. He purposed (time and money permitting) "to go round to other villages, eastern region, northern, and western regions [of Nigeria] to collect more folklores and then form them into books." ${ }^{0}$ Additionally, in 1962, Tutuola was invited by the German African Society to visit Germany for up to nine months on scholarship-an offer Tutuola had fully intended to accept. ${ }^{51}$ However, his repeated requests for leave from his position at the Nigerian Broadcasting Company were denied by his superiors because "this course of study has no immediate bearing on your present duties. Therefore it cannot be said to be designed to increase your efficiency as such." 52

Why was travel a factor in the modification of epistemologies and the distinction between Tutuola and the elite? As seen above, travel greatly impacted the perspective of the Ibadan writers. Until later in his career, Tutuola's geographic mobility was confined to his region of origin. Any additional travel would have been imagined through his correspondence with international agents and audience, any global news featured in Nigerian newspapers and radio broadcasts, and photographs and maps. One of Tutuola's notebooks from 1954, which he titled itan Yoruba ("Yoruba stories"), featured a map on its cover of Nigeria situated in the center of a broader West African context. ${ }^{53}$ Though he must have encountered maps elsewhere, what did it mean to Tutuola to visualize the space each time he opened the notebook to draft itan Yoruba? Additionally, around 1983 Tutuola received a postcard from London with an image of St. Paul's Cathedral at night. ${ }^{54}$ Such snapshots of foreign places undoubtedly contributed to Tutuola's self-awareness and epistemology,

49 E. M. Evans, letter to Tutuola, October 13, 1958, Box 10, Folder 7 (ATC-HRC).

50 Tutuola, quoted in "Amos Tutuola, Nigeria, August 1962. Interviewed by Lewis Nkosi, South Africa” (CRL).

51 Correspondence between Dr. Oskar Splett, Secretary General of the German African Society, and Tutuola, 1962, Box 6, Folder 2 (ATC-HRC).

52 E. M. Osakwe, letter to Tutuola, undated (but in response to Tutuola's request for leave in 1962), Box 10, Folder 7 (ATC-HRC).

53 Tutuola Holograph Manuscript, Box 3, Folder 5 (ATC-HRC).

54 Postcard from London, Box 6, Folder 1 (ATC-HRC). 
though not to the degree that elite identities and knowledges were impacted by time spent abroad.

The difference between material and imagined travel is perhaps most clearly exhibited in Tutuola's report, "A Brief Explanation of My Journey to America and London." In the opening lines, Tutuola remarks, "In 1983, when I was invited to America and London, all I met there were entirely different from what I thought before I left Nigeria. To my surprise all that I met in every state that I visited were the honour, fame and dignity, the kind of which I had not received since when I was born on earth." 55 Tutuola was also shocked to discover Yoruba artifacts in museums and shops in New Orleans and New York City. ${ }^{56}$ It is uncertain what Tutuola expected to find during his travels abroad, though likely his expectations would have been informed by his regular correspondence with American and British agents and audience. At least one opinion to which he had been previously exposed was that "American people were barbarous." 57 Tutuola wrote to a Japanese acquaintance, "Many thanks for the complimentary copy of CRIES FOR PEACE [. . .] I should have written to you about this book before this time but I passed it from one person to another just to read it and see what American people had done to Japanese people during the World War II [. . . I did this so that our people here might know that the American people had destroyed uncountable innocent people in Japan." 58

\section{Imagining Independent Nigeria}

On the eve of independence, Nigerian cities fluttered with enthusiasm, excitement, and euphoria. Elation was coupled with a sense of gravity, as African elites grappled with the future of their independent state. One of the young writers emerging from University College, Ibadan, Abiola Irele, recalls, "there were two contrary feelings at the time. We looked forward to independence, so there was this optimism, a more tremendous sense of the future [...] And there was this foreboding then of the future. All of a sudden, we realized that we had to reckon with certain factors-shall we say certain differences which we hadn't very seriously considered before then." ${ }^{59}$ Reflecting a similar sentiment sweeping across the continent more broadly, Tanganyikan political elite Julius Nyerere explained: "We are not so naïve that we do not realize the problems which new countries must face, and the anxious times through

55 Tutuola, "A Brief Explanation."

56 Ibid.

57 Tutuola, letter to Mr. Tomiya Akiyama, July 4, 1979, Box 6, Folder 4 (ATC-HRC).

58 Tutuola, letter to Mr. Tomiya Akiyama, July 4, 1979, Box 6, Folder 4 (ATC-HRC).

59 Abiola Irele, interview by Wren, Those Magical Years, 116. 
which such countries must pass." ${ }^{\prime 60}$ Yet, the sense of gravity adjoining independence in Africa was not presumed to be experienced among the general African population. William Arthur Lewis noted that "Politics touches the lives of very few [...] at present its dangers are confined to the relatively few who choose to play this game." ${ }^{11}$

Rather than being ignorant of the weight of independence, however, the average Nigerian merely imagined and articulated the new state differently than did the elite. Furthermore, the ways in which the future was envisioned by both elite and average was intimately linked to their educational experiences and their sociocultural identities. The language of politicians, for instance, reflected their unique situation at the top of a new hierarchy. In his aforementioned article, Nyerere defended the possibility of unity coexisting with democracy in Africa as African peoples struggled against European colonial authority. He believed: "It would surely be ridiculous to expect that a country should voluntarily divide itself for the sake of conforming to a particular expression of 'democracy' [...] during a struggle which calls for the complete unity of all its people." ${ }^{62}$ An important question arises from Nyerere's statement: who are all its people? And where were they in the nation-building project? What did unity mean to the general population, whose lives were lived farther away from "the game"? Or, how did the everyday African perceive the nation-state project in his own terms? In effort to answer these questions and recover an alternate vision for independent Africa, this section will analyze elements of Tutuola's imagined independence in comparison to that of the elite.

Educational and epistemological experiences informed the writers' visions for independent Nigeria. Related to his experience with and commitment to Yoruba storytelling, Tutuola sought a Nigeria in which African cultural traditions inherited from ancestors could still claim validity rather than being relegated to the status of superstition in favor of Western scientific knowledge. Along a different genealogy of thought, the Ibadan writers in the immediate aftermath of independence envisioned a new nation in which African cultural production could redeem the dignity of the African image globally and in which national loyalties overcame tribal loyalties. Their vision was informed by their privileged position as elite writers and cultural producers in Nigeria, their proximity to their nation's political leaders, and their interactions and regular discourse across ethnic lines at University College, Ibadan. It was also informed in response to Tutuola's life and work.

60 Julius Nyerere, "Will Democracy Work in Africa?” Africa Report 5 (Jan. 1, 1960): 3.

61 William Arthur Lewis, "Sources of Tension in West Africa," Africa Report 5 (Jan. 1, 1960): 5.

62 Nyerere, "Will Democracy Work in Africa?" 3. 
Tutuola and the elite promoted their different visions in different ways. One course of action taken by both sets of writers was to attempt to teach their nation the value of their respective visions, something Dipesh Chakrabarty has termed the "pedagogical mode" of decolonizing politics. ${ }^{63}$ Chakrabarty suggests that formerly colonized political elites identified themselves as "teachers to their nations." ${ }^{\prime 64}$ In the decolonizing moment, their particular brand of pedagogy was oriented toward a vision of modernity that would allow their new nations to "catch up' with the West." 65 Specifically related to the African context, Toyin Falola elaborates on the modernizing intentions of the educated elite. Falola asserts that African intellectuals sought "to retain an African identity and an Africa for Africans while reappropriating the West for the goal of progress." ${ }^{\prime 6}$ Such pedagogical impulses were exhibited among the literary elite in Nigeria. The Ibadan writers formed Western-style journals, publishing houses, and artist conferences in hopes of raising the standard of African cultural production and spearheading the development of the next generation of artists. Meanwhile, they debated what it meant to be African and write African literature.

Tutuola also positioned himself as a sort of teacher to the new Nigeria. Rather than privileging the West as a standard, however, his pedagogical approach privileged his inherited Yoruba culture and the indigenous knowledge it produced. Tutuola sought to teach Yoruba tradition, and he also sought to teach through Yoruba tradition. In a letter to one Elena Borelli, Tutuola wrote (1978): "Although I write my stories for the people to read but every Yoruba tale tells morals - or some sort of reasons: cautions-advantages and disadvantages-what is good and what is bad." ${ }^{67}$ Differences in vision and pedagogy refined the separation between elite and average. As Chakrabarty states: "This emphasis [by the political elite] on development as a catching-up-withthe-West produced a particular split that marked both the relationship between elite nations and their subaltern counterparts as well as that between elites and subalterns within national boundaries." ${ }^{\prime 68}$ Given his minimal education and limited upward mobility, Tutuola in relation to the educated elite represents the subaltern within the new nation's borders. Thus the vision and

63 Dipesh Chakrabarty, "The Legacies of Bandung: Decolonization and the Politics of Culture," in Making a World After Empire: The Bandung Moment and its Political Afterlives, ed. Christopher Lee (Athens: Ohio University Press, 2010), 46.

64 Chakrabarty, "The Legacies of Bandung," 54.

65 Ibid., 53.

66 Toyin Falola, Nationalism and African Intellectuals (Rochester, NY: University of Rochester Press, 2004), xviii.

67 Tutuola, letter to Miss Elena Borelli, August 21, 1978, Box 6, Folder 4 (ATC-HRC).

68 Chakrabarty, "The Legacies of Bandung," 53. 
pedagogy of Tutuola on behalf of his new state begin to uncover a subaltern method of development.

As a writer, Tutuola identified himself as being in a position to preserve Yoruba culture and knowledge for the sake of posterity. He imagined the writer's role as one who "write[s] useful books for the people of these present days and for those who are yet to be born." ${ }^{169}$ His work was meant to honor the potential of indigenous epistemology:

Thus the Yoruba folktales, beliefs, customs, proverbs, behaviors, etc., etc., which are belonged to us and which we don't take serious in our own land, are materials which I mixed up in my stories [.. . ] [W] have forgotten that those things which the ancient people had left for us are still in use [...] Therefore, I don't take all these things 'superstitions. ${ }^{70}$

His efforts were applauded, at least by some. In a letter to Tutuola signed K. A. Sey, "a teacher" from Aggrey College, Cape Coast, the teacher wrote: "I quite appreciate the excellent effort you are making to perpetuate our good old folk tales which at the present, seem to be fading away." ${ }^{11}$

As part of his commitment to traditional storytelling practices, Tutuola confronted the tension between individual significance and communal culture in the new Nigeria. He maintained that Yoruba folklore "belonged to us [the Yoruba community]." ${ }^{2}$ Nonetheless, Tutuola fought for his individual claim to authorship, ownership, and financial compensation. For instance, when Kola Ogunmola translated The Palm-Wine Drinkard into Yoruba and began performing the play on West African stages, Tutuola wrote to the Head of Drama at Ibadan requesting "[his] own share in the proceeds realised from the play since it has been in the market." 73 Five years later, when the play was supposed to be performed at the Algiers Festival of the Arts, a warning was circulated: "The Author of the Book, Palm Wine Drinkard, Mr. Amos Tutuola, has objected to the play adapted from his book [. . . Mr. Tutuola has declared that no permission has been sought [. . .]."74 Tutuola thus demonstrated what Obiechina has described as a flourishing democratic spirit among another group of subaltern writers: the pamphleteers at Onitsha. Their writing,

69 Tutuola, "A Brief Explanation."

70 Ibid.

71 K. A. Sey, letter to Tutuola, undated (but sometime after his first two books had been published and before Cape Coast became Ghana), Box 6, Folder 2 (ATC-HRC).

72 Tutuola, "A Brief Explanation."

73 Tutuola, letter to The Head of Drama, June 24, 1964, Box 6, Folder 2 (ATC-HRC).

74 Tutuola, “Warning," June 20, 1969, Box 6, Folder 2 (ATC-HRC). 
Obiechina suggests, reflected "a highly developed sense of human awareness and the acute insistence of individuals on their human relevance." 75

In January 1972, Tutuola was asked by Ken Iwai, Editor of Peace, Happiness and Prosperity for All magazine, to write on the theme, "What Is Freedom?"76 The result was a short essay that elaborates Tutuola's belief in the significance of individual Africans. Tutuola discussed the ideal freedom for individuals in this way: "[A] Freedom Man must have inherent capacity to make free choices [...] A Freedom Man is a man free to cater for himself in all aspects of living. He must be ready to shoulder all his responsibilities, and ready to encounter any adversity." 77 In terms of individual freedom within national borders, Tutuola wrote: "In an Independent Country without Freedom of speech and Freedom of movement, Country is liable to run into a series of difficulties, there will be unrest and chaos [. . .]." ${ }^{\prime 8}$ Individual freedom for Tutuola also found expression in collective freedom after independence. Tutuola believed: "It will be a National day for the Country, a day for merry making for the entire people of the Country, the government of the Country will be run by her people and not by her former masters." 79

In comparison, the elite vision for independent Nigeria attests to the constructed distance between Tutuola and his educated contemporaries. The Ibadan writers were influenced by elite political discourse, which sought an African-derived form of democracy. Nyerere labeled such African democracy communitary: "The traditional African community was a small one, and the African could not think of himself apart from his community [. . . he saw no struggle between his own interests and those of his community." ${ }^{\prime 0}$ Appropriating the historical memory of African community, the new African leaders envisioned independent states in which national loyalties overcame tribal loyalties. The literary elite, like their political counterparts, took on the vision of a unified Nigeria. Martin Banham, a European professor at Ibadan at the time, explained: "[The students] would have debates, they would behave as if they were above the petty grind of day-to-day politics. And I think they genuinely attempted to be." 81 The elite writers' hope for a unified Nigeria is reflected in Achebe's lecture, "The Role of the Writer in a New Nation" (1964). Regarding the question of language in Nigerian literature, Achebe argued "[S]ince I am considering the whole of the writer in building a new nation I

75 Obiechina, Literature for the Masses, 2.

76 Ken Iwai, letter to Tutuola, December 6, 1971, Box 6, Folder 3 (ATC-HRC).

77 Tutuola, "What Is Freedom?" Box 6, Folder 3 (ATC-HRC).

78 Ibid.

79 Ibid.

80 Nyerere, "Will Democracy Work in Africa?" 4.

81 Martin Banham, interview by Wren, Those Magical Years, 32. 
wish to concentrate on those who write for the whole nation whose audience cuts across tribe or clan. And these, for good or ill, are the writers in English" (emphasis in original). ${ }^{82}$

The Ibadan writers envisioned independent Nigeria from their position within elite circles. Banham described the Ibadan student body at the time as "politically conscious and politically involved with local and national politics." ${ }^{33}$ In his article "Nigeria's Youth Speaks Its Mind" (1961), Paul Conklin recaptured his encounter with a group of politically active Ibadan students. The students had protested together in early 1961 against the signing of the Anglo-Nigerian Defense Pact. They explained: "Africans are very weary of being pushed around like pawns on your Cold War chessboard [. . .] Russia and America haven't yet realized that Africa does not need to decide between capitalism and Communism. There are alternatives and we can find them." ${ }^{84}$ The elite writers also came face to face with the game of politics outside of the university. Abiole Irele often encountered Michael Imodu, a close friend of his father's and a leading political figure at the eve of independence, at his home. Imodu's presence made Irele aware of and excited by national politics. ${ }^{85} \mathrm{John}$ Pepper Clark recalled how "at the political level, we were very aware of what was happening in the country at large. It was people we knew who were in the seat of government [...]." 86

According to their vision for independent Nigeria and their position as privileged elites, the Ibadan writers intended to raise standards of cultural production. Achebe, for instance, wanted to address through his writing what he believed to be the fundamental challenge facing a new African nation like Nigeria: "what you might call a 'crisis in the soul' [. . . [T] he writer has the responsibility to teach his audience that there is nothing shameful about [elements of their traditional culture], that it is not only daffodils that can make a fit subject for poetry, but the palm tree and so on [. . .]." ${ }^{87} \mathrm{~J}$. P. Clark along with European professor Martin Banham ran a university publication, The Horn, to develop budding Ibadan writers. Soyinka started one of the earliest indigenous publishing houses of creative fiction, Orísun, and created a theater company to write and produce plays. As part of their development efforts, the

82 Achebe, "The Role of the Writer in a New Nation," Nigeria Magazine 81 (1964): 160. Originally a lecture delivered to the Nigerian Library Association.

83 Banham, interview by Wren, Those Magical Years, 32.

84 Student, quoted in Paul Conklin, "Nigeria's Youth Speaks Its Mind," Africa Report 6, no. 3 (March 1, 1961): 2.

85 Irele, interview by Wren, Those Magical Years, 116.

86 John Pepper Clark, interview by Wren, Those Magical Years, 111.

87 Achebe, quoted in "Chinua Achebe, Nigeria, September 1964. Interviewed by Donatus Nwoga, Nigeria,” (CRL). 
Ibadan writers sought to develop a new standard of "good" African literature, one that would challenge an ongoing history of European prejudices. Soyinka explained, "European foreign critics are not helping by applying a different standard for writing literature, I think they're always astonished that anything can come out of Africa at all." 88

The elite vision for independent Nigeria was also shaped in response to the life and work of Tutuola. As mentioned above, Tutuola became a talking point at elite literary meetings and conferences, where his unconventional English reinforced beliefs that higher education should be a prerequisite for the nation's leaders. In his aforementioned lecture, "The Role of the Writer," Achebe emphasized the importance of a writer's proficiency in English. On English being adapted by writers to better suit African experiences and modes of thought, he stated:

But it [the adaptation of English] can also get out of hand. It can lead to simply bad English being accepted and defended as African or Nigerian. I submit that those who can do the work of extending the frontiers of English so as to accommodate African thought-patterns must do it through their mastery of English and not out of innocence. Of course, there is the obvious exception of Amos Tutuola. But even there it is possible that he has said something unique and interesting in a way that is not susceptible to further development. (emphasis in original) ${ }^{89}$

In this way, the elite writers set themselves apart from Tutuola, imagined themselves as literary teachers, and established new standards for African literary production according to their vision of their independent state. Tutuola remained a marginal comment in their discourse.

\section{Conclusion}

Tutuola's literary success blurred the line between elite and average, giving the subaltern writer access to national and international notoriety. At the same time, however, his work brought into focus the constructed division between the two groups. Despite his position as the first internationally published, English-language Nigerian author, Tutuola was differentiated from the Ibadan writers on the basis of education and epistemology. His work was relegated to the margins of elite literary discourse. Meanwhile, the elite were able to reinforce their distance from Tutuola via the language and perspective of

88 Soyinka, quoted in "Wole Soyinka, Nigeria, September 1962. Interviewed by Lewis Nkosi, South Africa," (CRL).

89 Achebe, "The Role of the Writer in a New Nation," 160. 
Western academia. From their vision of a modern independent Nigeria came efforts to develop a new African literature after their own image.

For his part, Tutuola positioned himself as a distinctly Yoruba writer in the new Nigeria. He envisioned a state in which traditional knowledge remained central to the African identity. On behalf of his vision, Tutuola committed his writing to the perpetuation of a Yoruba worldview. Far from being ignorant of the gravity of independence, his hand-drafted folktales became a space through which he wrestled with Africa's transition. To Obiechina, Tutuola exemplified the capability of the average African. In his article, "Amos Tutuola and the Oral Tradition" (1968), Obiechina argued: "[T]he popular image of the traditional African as the helpless victim of his hostile environment is contrary to that held by the African of himself, as reflected in traditional folktales. The African is aware of the problems, physical and otherwise, which surround him and threaten his survival, but is immensely confident in his ability to face up to these problems by his courage and mental resourcefulness." ${ }^{90}$ Ultimately, Tutuola engaged with ideas of independence through his actions, by recording and reappropriating Yoruba folklore, rather than in academic discourse. His life and work attest to the endurance of indigenous epistemology through years of European colonialism and into independence.

\section{Archive Collections}

\section{REFERENCES}

Amos Tutuola Collection, Harry Ransom Humanities Research Center, University of Texas.

The Transcription Centre Records, Harry Ransom Humanities Research Center, University of Texas.

\section{Digital Archive Collections}

“Africa, Black African writers and playwrights, 1962-1968." Digitized transcripts of sound recordings by The Transcription Center (London) in various locations, ca. 1962-1969. http://www.crl.edu/.

"Africa, Black writers and poets 1962-1966." Digitized transcripts of sound recordings by The Transcription Center (London) in various locations, ca. 1962-1969. http://www.crl.edu/.

"Africa, interviews with Black African writers and artists, ca. 1962-1969." Digitized transcripts of sound recordings by The Transcription Center (London) in various locations, ca. 1962-1969. http://www.crl.edu/.

90 Emmanuel Obiechina, "Amos Tutuola and the Oral Tradition," Présence Africaine 65 (1968): 85-106, in Bernth Lindfors, ed., Critical Perspectives on Amos Tutuola (Washington, D.C.: Three Continents Press, 1975), 94. 
"Africa, Lectures with Black African writers and artists, 1962-1966." Digitized transcripts of sound recordings by The Transcription Center (London) in various locations, ca. 1962-1969. http://www.crl.edu/.

"African writers: Alex La Guma on Amos Tutuola, Jan 1967."

"African writers: Ali Mazrui, Nov 1962, 'The Mind of Africa' by W. Abraham." Africa Abroad, no. 15. November 15, 1962.

Amos Tutuola, Nigeria, August 1962. Interviewed by Lewis Nkosi, South Africa.

Chinua Achebe, Nigeria, April 1968. Interviewed by Jack Ludwig, Canada.

Chinua Achebe, Nigeria, August 1962. Interviewed by Lewis Nkosi, South Africa.

Chinua Achebe, Nigeria, February 1967. Interviewed by Robert Serumaga, Uganda.

Chinua Achebe, Nigeria, September 1964. Interviewed by Donatus Nwoga, Nigeria.

Chinua Achebe, Nigeria, September 1965. Interviewed by Dennis Duerden, United Kingdom.

Christopher Okigbo, Nigeria, August 1962. Interviewed by Lewis Nkosi, South Africa.

Christopher Okigbo, Nigeria, August 1963. Interviewed by Dennis Duerden, United Kingdom.

Christopher Okigbo, Nigeria, July 1965. Interviewed by Robert Serumaga, Uganda.

Christopher Okigbo, Nigeria, July 1965. Interviewed by Robert Serumaga, Uganda.

Cyprian Ekwensi, Nigeria, August 1962. Interviewed by Lewis Nkosi, South Africa.

Cyprian Ekwensi, Nigeria, November 1964. Interviewed by Dennis Duerden, United Kingdom.

"Discussion: 'The African Image'." Lewis Nkosi (chair), Ezekiel Mphahlele, David Rubadiri, Donatus Nwoga, and Joseph Kariuki, April 11, 1962.

“Discussion: African Literature." Lewis Nkosi, Donatus Nwoga, Barry Reckord, June 1962.

"Discussion: West African Writing." Ezekiel Mphalele (chair), George Awoonor-Williams, John Pepper Clark, Summer 1962.

"Discussion: What is African Literature, at African Writers Conference, Makerere, 1962." Lewis Nkosi, Langston Hughes, Barry Reckord, Bernard Fonlon, Christopher Okigbo, June 1962.

Donatus Nwoga, Nigeria, June 1964. Interviewed by Dennis Duerden, United Kingdom. 
Gabriel Okara, Nigeria, September 1964. Interviewed by Andrew Salkey, Trinidad.

John Pepper Clark, Nigeria, January 1964. Interviewed by Andrew Salkey, Trinidad.

John Pepper Clark, Nigeria, September 1962. Interviewed by Lewis Nkosi, South Africa.

John Pepper Clark, Nigeria, September 1964. Interviewed by Andrew Salkey, Trinidad.

S. Okechukwu Mezu, Nigeria, October 1969. Interviewed by Maxine Lautre, South Africa.

“Three Nigerian Novelists." Written by Donatus Nwoga, narrated by Nelson Ipaye, April 1962.

Wale Ogunyemi, Nigeria, May 1968. Interviewed by Maxine Lautre, South Africa.

Wole Soyinka, Nigeria, August 1965. Interviewed by Dennis Duerden, United Kingdom.

Wole Soyinka, Nigeria, May 1962. Interviewed by Ezekiel Mphahlele, South Africa.

Wole Soyinka, Nigeria, September 1962. Interviewed by Lewis Nkosi, South Africa.

Zulu Sofola, Nigera, May 1968. Interviewed by Maxine Lautre, South Africa.

\section{Published Interviews}

Di Maio, Alessandra. Tutuola at the University: The Italian Voice of a Yoruba Ancestor, with an Interview with the Author and an Afterword by Claudio Gorlier. Rome: Bulzoni, 2000.

Wren, Robert M. Those Magical Years: The Making of Nigerian Literature at Ibadan, 1948-1966. Washington, D.C.: Three Continents Press, 1990.

\section{Other Primary Sources}

"African Fiction: Part I." Africa Report 7, no. 9 (Oct 01, 1962): 3.

"African Literature, Part II: English-Speaking West Africa." Africa Report 7, no. 11 (Dec. 1, 1962): 15.

Achebe, Chinua. "The Role of the Writer in a New Nation." Nigeria Magazine 81 (1964): 157-160.

Africa Report, 1960-1970.

Armstrong, Robert P. "Book Publishing in Nigeria: Industry with a Future." Africa Report 11, no. 4 (April 1, 1966): 56.

Collings, Rex. "Publishing in Africa." Africa Report 15, no. 8 (Nov. 1, 1970): 31. "Conversation with Amos Tutuola." Africa Report 9, no. 7 (July 1, 1964): 7.

"Conversation with Chinua Achebe." Africa Report 9, no. 7 (July 1, 1964): 7. 
“Conversation with Ezekiel Mphahlele." Africa Report 9, no. 7 (July 1, 1964): 7.

"Conversation with Ulli Beier." Africa Report 9, no. 7 (July 1, 1964$): 7$.

Gérard, Albert, S. “The Neo-African Novel.” Africa Report 9, no. 7 (July 1, 1964): 3.

Lindfors, Bernth. "Nigerian Novels of 1965." Africa Report 11, no. 6 (June 1, 1966): 68.

“The Makerere Writers' Conference.” Africa Report 7, no. 7 (July 1, 1962): 7.

Nkosi, Lewis. "Where Does African Literature Go from Here?" Africa Report 11, no. 9 (Dec. 1, 1966): 7.

Nyerere, Julius. "Will Democracy Work in Africa?" Africa Report 5, (Jan. 1, 1960): 2.

Schmidt, Nancy J. "Nigeria: Fiction for the Average Man." Africa Report 10, no. 8 (Aug. 1, 1965): 39.

Williams, Babatunde A. "Where does Nigeria Go from here?" Africa Report 5, (Jan. 1, 1960): 5 .

Wonodi, Okogbule. "The Role of Folk Tales in African Society." Africa Report 10, no. 11 (Dec. 1, 1965): 17.

\section{Reviews of Tutuola}

"Portrait: A Life in the Bush of Ghosts." West Africa (May 1, 1954). In Critical Perspectives on Amos Tutuola, edited by Bernth Lindfors, 35-38. Washington, D.C.: Three Continents Press, 1975.

Agbebiyi, Gladys. Letter to Nigeria Magazine (March/May 1968). In Critical Perspectives on Amos Tutuola, edited by Bernth Lindfors, 103. Washington, D.C.: Three Continents Press, 1975.

Akinjogbin, I. Adeagbo. Letter to West Africa (June 5, 1954). In Critical Perspectives on Amos Tutuola, edited by Bernth Lindfors, 41. Washington, D.C.: Three Continents Press, 1975.

Anozie, Sunday O. "Amos Tutuola: Literature and Folklore, or the Problem of Synthesis." Cahiers d'Etudes Africaines 10, 38 (1970): 335-51, translated by Judith H. McDowell. In Critical Perspectives on Amos Tutuola, edited by Bernth Lindfors, 237-253. Washington, D.C.: Three Continents Press, 1975.

Beier, Ulli (as "Akanji”). "The Brave African Huntress by Amos Tutuola." Black Orpheus 4 (October 1958): 51-53. In Critical Perspectives on Amos Tutuola, edited by Bernth Lindfors, 83-85. Washington, D.C.: Three Continents Press, 1975.

Collins, Harold R. Amos Tutuola. New York: Twayne Publishers, Inc., 1969.

- - - "Founding a New National Literature: The Ghost Novels of Amos Tutuola." Critique 4, 1 (1961): 17-28. In Critical Perspectives on Amos Tutuola, edited by Bernth Lindfors, 59-70. Washington, D.C.: Three Continents Press, 1975. 
Jones, Eldred. "The Palm Wine Drinkard: Fourteen Years On.” The Bulletin of the Association for African Literature in English 4 (1966): 24-30. In Critical Perspectives on Amos Tutuola, edited by Bernth Lindfors, 109-113. Washington, D.C.: Three Continents Press, 1975.

Lindfors, Bernth. "Amos Tutuola: Debts and Assets." Cahiers d'Études Africaines 10, no. 38 (1970): 306-334.

Liyong, Taban lo. “Tutuola, Son of Zinjanthropus." Busura 1, no. 1 (1968): 308. In Critical Perspectives on Amos Tutuola, edited by Bernth Lindfors, 115122. Washington, D.C.: Three Continents Press, 1975.

Mackay, Mercedes. Letter to West Africa (May 8, 1954). In Critical Perspectives on Amos Tutuola, edited by Bernth Lindfors, 43-44. Washington, D.C.: Three Continents Press, 1975.

Moore, Gerald. "Amos Tutuola: A Nigerian Visionary." Black Orpheus 1 (September 1957): 27-35. In Critical Perspectives on Amos Tutuola, edited by Bernth Lindfors, 49-57. Washington, D.C.: Three Continents Press, 1975.

Neumarkt, Paul. “Amos Tutuola: Emerging African Literature." American Imago 28 (1971): 129-45. In Critical Perspectives on Amos Tutuola, edited by Bernth Lindfors, 183-192. Washington, D.C.: Three Continents Press, 1975.

Obiechina, Emmanuel N. "Amos Tutuola and the Oral Tradition." Présence Africaine 65 (1968): 85-106 In Critical Perspectives on Amos Tutuola, edited by Bernth Lindfors, 123-144. Washington, D.C.: Three Continents Press, 1975. Revised and republished in Language and Theme: Essays on African Literature. Washington, D.C.: Howard University Press, 1990, 21-52.

\section{Secondary Sources}

Boateng, Boatema. The Copyright Thing Doesn't Work Here: Adinkra and Kente Cloth and Intellectual Property in Ghana. Minneapolis: University of Minnesota Press, 2011.

Chakrabarty, Dipesh. "The Legacies of Bandung: Decolonization and the Politics of Culture." In Making a World After Empire: The Bandung Moment and Its Political Afterlives, edited by Christopher J. Lee, 45-68. Athens: Ohio University Press, 2010.

Falola, Toyin. Nationalism and African Intellectuals. Rochester, NY: University of Rochester Press, 2004.

Feierman, Steven. Peasant Intellectuals: Anthropology and History in Tanzania. Madison: University of Wisconsin Press, 1990.

Obiechina, Emmanuel N. "Amos Tutuola and the Oral Tradition." Présence Africaine 65 (1968): 85-106; revised in Language and Theme: Essays on African Literature. Washington D.C.: Howard University Press, 1990, 21-52. 
- - Literature for the Masses: An Analytical Study of Popular Pamphleteering in Nigeria. Enugu, Nigeria: Nwankwo-Ifejika, 1971. 